\title{
PENGARUH KEPEMIMPINAN UNTUK MENCIPTAKAN KINERJA KARYAWAN DALAM ORGANISASI
}

\author{
Luthfia Sabrina \\ Universitas Negeri Padang \\ Indonesia
}

\section{Email : sabrinarinaluthfia@gmail.com}

\begin{abstract}
Abstrak- Tujuan penelitian ini adalah untuk mengungkapkan pengaruh kepemimpinan untuk menciptakan kinerja karyawan dalam organisasi. Hasil penelitian menunjukkan bahwa untuk meningkatkan kinerja karyawan dalam organisasi, dibutuhkan seorang pemimpin yang mampu membawa organisasi mengarah pada tujuan. Pimpinan yang sukses adalah apabila pemimpin tersebut mampu menjadi pencipta dan pendorong bagi bawahannya dengan menciptakan kinerja organisasi yang dapat memacu pertumbuhan dan perkembangan organisasinya. Pemimpin tersebut memiliki kemampuan memiliki kemampuan untuk memberikan pengaruh positif bagi pegawainya untuk melakukan pekerjaan sesuai dengan yang diarahkan dalam rangka mencapai tujuan yang ditetapkan. Dalam rangka meningkatkan kinerja organisasi perlu peran aktif dari pimpinan untuk memberikan dorongan atau motivasi dengan cara memberikan pemenuhan kebutuhan baik fisik maupun psikologis pada batas-batas kelayakan.
\end{abstract}

Kata Kunci: Pengaruh Kepemimpinan, Kinerja Karyawan Dalam Organisasi

\section{PENDAHULUAN}

Kepemimpinan/

merupakan topik yang menerik

perhatian banyak orang dan didefenisikan dengan banyak cara. Kepemimpinan dapat didefenisikan berdasarkan ciri-ciri, perilaku, pengaruh, pola interaksi, hubungan peran, dan posisi jabatan administratif. Sebagian besar defenisi kepemimpinan mencerminkan asumsi bahwa kepemimpinan berkaitan dengan proses yang dilakukan oleh seseorang untuk mempengaruhi orang lai, membimbing, membuat struktur, memfasilitasi aktivitas, dan hubungan di dalam suatu kelompok maupun organisasi. Yukl 
(2007) dalam Danang Suryanto dan Burhanuddin (2011:85).

Dalam organisasi apapaun bentuknya, kepemimpinan merupakan faktor yang turut menentukan tercapainya tujuan organisasi secara lebih efektif dan efisien. Pemimpin merupakan simbol, panutan, pendorong, sekaligus sumber daya organisasi guna mencapai tujuannya.

Gaya kepemimpinan merupakan norma perilaku yang digunakan oleh seorang pemimpin pada saat memimpin tersebut mencoba untuk mempengaruhi orang lain. Dalam teori kepemimpinan ada beberapa gaya kepemimpinan yang dapat digunakan. Kemampuan seorang pemimpin dalam mempengaruhi pengikutnya merupakan faktor dominan yang menentukan keberhasilan suatu organisasi, karena kepemimpinan memiliki peran sebagai koorddinator, motivator, dan katalis yang akan membawa organisasi pada puncak keberhasilan.

Dalam rangka meningkatkan kinerja kinerja karyawan dalam organisasi, dibutuhkan seorang pemimpin yang mampu membawa organisasi mengarah pada tujuan. Pimpinan yang sukses adalah apabila pemimpin tersebut mampu menjadi pencipta dan pendorong bagi bawahannya dengan menciptakan kinerja organisasi yang dapat memacu pertumbuhan dan perkembangan organisasinya. Pemimpin tersebut memiliki kemampuan memiliki kemampuan untuk memberikan pengaruh positif bagi pegawainya untuk melakukan pekerjaan sesuai dengan yang diarahkan dalam rangka mencapai tujuan yang ditetapkan. Kepemimpinan yang efektif harus menggunakan gaya kepemimpinan yang berbeda dalam situasi yang berbeda, tidak bergantung pada satu pendekatan untuk semua situasi, menentukan gaya yang sesuai untuk situasi tertentu serta mampu menggunakannya dengan benar.

\section{METODE PENELITIAN}

Artikel ilmiah hendaknya disusun dengan metode dan langkah-langkah yang sistematis untuk memudahkan melakukan penelitian. Pada artikel ini, peneliti menggunakan metode studi literatur dengan cara mengumpulkan literatur (bahan-bahan materi) yang bersumber dari buku, jurnal, dan sumber lainnya terkait ilmu tentang Kepemimpinan.

\section{PEMBAHASAN}

\section{A. Pengertian Kepemimpinan \\ Pimpinan menjadi salah satu faktor penentu keberhasilan suatu organisasi.}


Pendapat ini di dukung oleh (Tia Ayu Ningrum, 2014) citra organisasi dapat terbentuk dari adanya persepsi yang berkembang dibenak publik terhadap realitas. Pimpinan merupakan seorang yang mengarahkan suatu aktivitas yang ada di organisasi dan mempunyai tanggung jawab yang besar atas bawahan dan sumber daya organisasi lainnya untuk mencapai tujuan bersama.

Selain itu, seorang pimpinan merupakan orang yang harus mampu dan memiliki keberanian dalam mengambil keputusan terhadap masalah-masalah yang dihadapi oleh organisasi.

Kepemimpinan/ merupakan topik yang menarik perhatian banyak orang dan didefenisikan dengan banyak cara. Kepemimpinan dapat didefenisikan berdasarkan ciri-ciri, perilaku, pengaruh, pola interaksi, hubungan peran, dan posisi jabatan administratif. Sebagian besar defenisi kepemimpinan mencerminkan asumsi bahwa kepemimpinan berkaitan dengan proses yang dilakukan oleh seseorang untuk mempengaruhi orang lai, membimbing, membuat struktur, memfasilitasi aktivitas, dan hubungan di dalam suatu kelompok maupun organisasi.

Kepemimpinan adalah kegiatan mempengaruhi orang-orang agar mereka suka berusaha mencapai tujuan-tujuan kelompok. George R.Terry dalam Kartini Kartono (2005:57).

Hasibuan (2003:170) juga mengemukakan "Kepemimpinan adalah cara seorang pemimpin mempengaruhi perilaku bawahan agar mau bekerja sama dan bekerja secara efektif dan efisien untuk mencapai tujuan organisasi.

Indikator kepemimpinan menurut wahjosumidjo (1991:154) diantaranya adalah:

1) Bersifat adil

Dalam kegiatan suatu organisasi, rasa keberrasamaan diantara para anggota adalah mutlak, sebab rasa kebersamaan pada hakikatnya merupakan pencerminan dari pada kesepakatan antara para bawahan maupun antara pemimpin dengan bawahan dalam mencapai tujuan organisasi.

2) Memberi sugesti

Sugesti biasanya disebut sebagai saran atau anjuran. Dalam rangka kepemimpinan, sugesti merupakan pengaruh dan sebaginya, yang mampu menggerakkan hati orang lain dan sugesti mempunyai peranan yang sangat penting di dalam memelihara dan membina harga diri serta rasa pengabdian, partisipasi, 
dan rasa kebersamaan diantara para bawahan.

3) Mendukung tujuan

Tercapainya tujuan organisasi terbentuk, melainkan harus didukung oleh adanya kepemimpinan. Oleh karena itu, agar setiap organisasi dapat efektif dalam arti mampu mencapai tujuan yang telah ditetapkan, maka setiap tujuan yang ingin dicapai perlu disesuaikan dengan keadaan organisasi serta memungkinkan para bawahan untuk bekerja sama.

4) Katalisator

Seorang pemimpin dikatakan berperan sebagai katalisator, apabila pemimpin itu selalu dapat meningkatkan segala sumber daya manusia yang ada, berusaha memberikan reaksi yang menimbulkan semangat dan daya kerja cepat semaksimal mungkin.

5) Menciptakan rasa aman

Setiap pemimpin berkewajiban menciptakan rasa aman bagi para bawahannya. Dan ini hanya dapat dilaksanakan apabila setipa pemimpin mampu memelihara hal-hal yang positif, sikap optimisme di dalam mengahadapi segala permasalahan.

6) Sebagai wakil organisasi
Setiap bawahan yang bekerja pada unit organisasi apapun, selalu memandang atasan atau pimpinannya mempunyai peranan dalam segala bidang kegiatan, lebih-lebih yang menganut prinsip-prinsip keteladanan atau panutan-panutan.

7) Sumber inspirasi

Seorang pemimpin pada hakikatnya adalah sumber semangat bagi para bawahannya. Oleh karena itu, setiap pemimpin harus selalu dapat membangkitkan semangat para bawahan sehingga bawahan menerima dan memahami tujuan organisasi dengan antusias dan bekerja secara efektif ke arah tercapainya tujuan organisasi.

8) Bersikap menghargai

Setiap orang pada dasarnya menghendaki adanya pengakuan dan penghargaan diri pada orang lain. Demikian pula setiap bawahan dalam organisasi memerlukan adanya pengakuan dan penghargaan dari atasan. Oleh karena itu, menjadi suatu kewajiban bagi pemimpin untuk mau memberikanpenghargaan untuk mau memberikan penghargaan atau pengakuan dalam bentuk apapun kepada bawahannya. Jadi, kepemimpinan adalah proses dimana seseorang atau pemimpin 
mempengaruhi pengikutnya dengan cara-cara yang tidak memaksa untuk mencapai satu tujuan.

\section{B. Kinerja Organisasi}

Kinerja merupakan suatu sikap dan perilaku pegawai dalam organisasi terhadap peraturan-peraturan dan standar-standar yang telah ditetapkan oleh organisasi yang telah diwujudkan baik dalam bentuk tingkah laku maupun perbuatan. Secara umum kinerja diartikan sebagai hubungan antara hasil nyata maupun fisik, misalnya ukuran efisiensi produksi yaitu suatu perbandingan antara hasil keluar dan masuk.

Kinerja adalah kondisi dari sebuah kelompok di mana ada tujuan yang jelas dan tetap yang diraskan menjadi penting dan terpadu dengan tujuan individu (Panggabean, 2004). Menurut Nitisemito (2003), kinerja adalah melakukan pekerjaan secara lebih giat, sehingga dengan demikian pekerjaan akan diharapkan lebih cepat dan lebih baik.

Seseorang akan selalu mendambakan penghargaan terhadap hasil pekerjaannya dan mengharapkan imbalan yang adil. Penilaian kinerja perlu dilakukan subyektif mungkin karena akan memotivasi karyawan dalam melakukan kegiatannya. Berbagai macam jenis karyawan tentunya membutuhkan kriteria yang jelas, karena masing-masing jenis pekerjaan tentunya mempunyai standar yang berbeda-beda tentang pencapaian hasilnya. Makin rumit jenis pekerjaan, maka standard operating procedure yang ditetapkan akan menjadi syarat mutlak yang harus dipatuhi.

Mangkunegara (2006) menyatakan kinerja organisasi dapat didefenisikan sebagai hasil kerja secara kualitas dan kuantitas yang dapat dicapai oleh seseorang pegawai dalam melaksanakan tugas sesuai tanggungjawab yang diberikan kepadanya. Evaluasi kinerja adalah penilaian yang dilakukan secara sistematis untuk mengetahui hasil pekerjaan karyawan dan kinerja organisasi.

Dalam rangka meningkatkan kinerja organisasi perlu peran aktif dari pimpinan untuk memberikan dorongan atau motivasi dengan cara memberikan pemenuhan kebutuhan baik fisik maupun psikologis pada batas-batas kelayakan. Dengan demikian, kepuasan kerja pegawai juga akan dapat tercapai. Di sisi lain nilai usaha pegawai akan semakin ditingkatkan, karena didorong oleh munculnya harapan-harapan baru. Sementara itu untuk mengimbangi usahanya dalam bekerja pegawai akan meningkatkan kemampuan yang 
sepadan, sehingga mampu mencapai kinerja yang maksimal.

Disamping itu, pimpinan hendaknya mampu menyampaikan dan mengkomunikasikan tujuan organisasi secara jelas, tujuan kinerja yang jelas, serta membuka peluang lebar untuk memaksimalkan usaha dari kinerja pegawai.

\section{Pengaruh Kepemimpinan Untuk}

\section{Menciptakan Kinerja Organisasi}

Hubungan kepemimpinan dengan kinerja organisasi fungsi kepemimpinan yang paling penting adalah memberikan motivasi kepada bawahannya, kepemimpinan diyakini memiliki pengaruh terhadap kinerja bawahan dari suatu organisasi. Pemimpin memotivasi pengikutnya untuk melakukan sesuatu (kinerja) diluar dugaan melalui transformasi pemikiran dan sikap mereka untuk mencapai kinerja diluar dugaan tersebut, pemimpin menunjukkan berbagai perilaku yaitu : pengaruh idealisme, motivasi insporasional, stimulasi intelektual dan konsiderasi individual. Ttidak hanya itu pengalaman masa lalu juga dapat mempengaruhi kinerja. Dengan adanya motivasi, maka terjadilah kemauan untuk bekerja sama dengan adanya kerja sama, maka kinerja suatu organisasi akan meningkat. Kinerja organisasi akan meningkat, apabila bawahan dalam suatu organisasi dapat bekerja sama dan menghasilkan hasil yang baik.

\section{KESIMPULAN DAN SARAN}

\section{A. Kesimpulan}

Dari pembahasan tersebut maka dapat disimpulkan bahwa untuk meningkatkan kinerja organisasi, dibutuhkan seorang pemimpin yang mampu membawa organisasi mengarah pada tujuan. Pimpinan yang sukses adalah apabila pemimpin tersebut mampu menjadi pencipta dan pendorong bagi bawahannya dengan menciptakan kinerja organisasi yang dapat memacu pertumbuhan dan perkembangan organisasinya. Pemimpin tersebut memiliki kemampuan memiliki kemampuan untuk memberikan pengaruh positif bagi pegawainya untuk melakukan pekerjaan sesuai dengan yang diarahkan dalam rangka mencapai tujuan yang ditetapkan.

Dalam rangka meningkatkan kinerja organisasi perlu peran aktif dari pimpinan untuk memberikan dorongan atau motivasi dengan cara memberikan pemenuhan kebutuhan baik fisik maupun psikologis pada batas-batas kelayakan. Dengan demikian, kepuasan kerja pegawai juga akan dapat tercapai. Di sisi lain nilai usaha pegawai akan 
semakin ditingkatkan, karena didorong oleh munculnya harapan-harapan baru. Sementara itu untuk mengimbangi usahanya dalam bekerja pegawai akan meningkatkan kemampuan yang sepadan, sehingga mampu mencapai kinerja yang maksimal.

\section{B. Saran}

Seorang peimpinan hendaknya mampu menyampaikan dan

\section{Daftar Pustaka}

Tia Ayu Ningrum. Peningkatan Efektivitas Komunikasi Publik Untuk Membangun Citra Di Sekolah Menengah Kejuruan Nusatama Padang (2014).

Kartono, Kartini, 2004. Pemimpin Dan

Kepemimpinan Abnormal Itu. Jakarta : Rajawali Press.

Mangkunegara, 2006. Evaluasi Kinerja

Sumber Daya Manusia . Bandung :

PT. Refika Aditama.

Hasibuan, M. 2003. Organisasi dan Motivasi. Jakarta: PT. Bumi Aksara. Panggabean, S, Mutiara. 2004.

Manajemen Sumber Daya Manusia.

Bogor: Ghalia Indonesia.

Wahjosumidjo. 1991. Kepemimpinan yang Efektif. Yogyakarta: Balai Pustaka. mengkomunikasikan tujuan organisasi secara jelas, tujuan kinerja yang jelas, serta membuka peluang lebar untuk memaksimalkan usaha dari kinerja pegawai. 